\title{
Global risks and tourism industry in Turkey
}

\author{
Ali Asgary ${ }^{1,2} \cdot$ Ali lhsan Ozdemir ${ }^{2} \mathbb{D}$
}

Published online: 1 June 2019

(c) Springer Nature B.V. 2019

\begin{abstract}
This study applies the World Economic Forum's global risk report methodology at a country and industry specific level to understand how the national as well as the industry contexts and conditions affect perceptions of the global risks, using the case of tourism industry in Turkey. Data was collected from a sample of respondents involved in tourism industry through an online questionnaire. Findings shows that significant variances exist between the perceived likelihoods and impacts of global risks and their ranks at the global and the country/industry levels. These findings demonstrate that for country level actors at specific industries such as tourism the global risks can be viewed and evaluated differently. Particularly, the global economic risks and the global geopolitical risks are perceived by the respondents to be more likely to occur and have more impacts compared to the global environmental and technological risks. Subsequently, the rankings of the risks and the top five risks are also very different between the global and the country/industry specific levels. Considering the importance of tourism for the global and national economies, it is important that global risks are analyzed and monitored at national and regional levels. This will provide policy and decision makers with more information to manage the risks and tourism industry based on the interrelationships that exist between the global risks and the tourism.
\end{abstract}

Keywords Global risks · Tourism · Turkey $\cdot$ Risk assessment $\cdot$ Risk matrix

\section{Introduction}

The international community is facing with many risks and complex and interrelated political, social and environmental trends such as urbanization, aging population, environmental degradation, cyber dependency (de Amorim et al. 2018; World Economic Forum 2019). If these risks are not analyzed, assessed and managed properly and these trends continue with

Ali Ihsan Ozdemir

aliozdemir@ybu.edu.tr

Ali Asgary

asgary@yorku.ca

1 Disaster and Emergency Management, School of Administrative Studies, York University, 4700

Keele Street, Toronto, ON M3J 1P3, Canada

2 Business Administation Department, Ankara Yıldırım Beyazıt University, Business School, Esenboğa Campus, Ankara, Turkey 
their current pace, they can create major challenges for the global community. Everything else remains constant, just because the global population is rising, these risks will also rise. With 8.5 billion population most of them living in urban areas subject to many different hazards, the risk will be higher in 2030 than today and much higher in 2050 when the world population is estimated to reach to 9.7 billion (UN 2015).

World Economic Forum (WEF) has been monitoring, analyzing and reporting a list of 30 global risks using a survey of about 1000 global players and stakeholders since 2005. World Economic Forum (2019) defines the global risk as "an uncertain event or condition that, if it occurs, can cause significant negative impact for several countries or industries within the next 10 years" (p. 100). These risks can affect people and businesses around the globe with potential security, health, environmental, economic and technological impacts (de Amorim et al. 2018; 3). Moreover, global risks are systemic risks, meaning that they have the potential to impact the entire globe through various growing interconnections and interdependencies (Kaufman and Scott 2003). These risks are also linked with many global trends with their unexpected and unpredicted consequences (Engel and Strasser 1998; Cutter et al. 2015). Most of the 30 risks introduced in the Global Risk Report (GRR) (World Economic Forum 2019) can directly or indirectly impact tourism industry. Tourism can also be a driving force in creating or reducing some of these risks depending on how well planned and manages it is.

The main objective of this study is to understand how the global risks are viewed and perceived at national level in tourism industry using the case of Turkey. Tourism industry is selected because it is one of the key and growing sectors in the national and global economies. In 2018, the sector's total contribution to the global GDP reached to US\$8.8 trillion (WTTC 2019). Tourism accounted for about $10.4 \%$ of the global GDP and 319 million jobs, or $10 \%$ of the total employment in 2018. Tourism sector is expected to continue its growth in 2019 despite the slowing global economy due to visa relaxation and economic policies (WTTC 2019). However, this growth can be challenged by the global risks.

Turkey is a good case study because Turkey is a country with high levels of tourism activities and a country that has recently experienced some of the global economic, environmental, geopolitical, societal, and technological risks. Turkey has made important progress in tourism during the past few decades. In 1990s the number of international tourists was 5.3 million, this number exceeded 10 million in 2000s, and reached to 40 million in 2018 (Culture and Tourism Ministry 2018). Turkey was in 14th rank in the world ranking in terms of tourism revenues and in 8th rank in terms of inbound number of tourists in 2017 (Culture and Tourism Ministry 2018). Turkey gained \$ 29.5 billion from tourism in 2018 (Culture and Tourism Ministry 2018) and aims to reach this to 50 million tourists and $\$ 50$ billion income by 2023.

The remaining parts of this paper are organized as follows. Section 2 provides some background on global risks and their relationship with tourism. Section 3 discusses the methodology and data used in this study. Section 4 presents the key findings followed by some discussion in Sect. 5. Finally, Sect. 6 concludes the paper with some research and policy recommendations.

\section{Background: global risks and tourism}

The 2019 GRR (World Economic Forum 2019) examines 30 global risks and classifies them under five major categories including: economic, environmental, geopolitical, societal and technological. In this section we examine these risks and their implications for 
tourism sector in general with some reference to Turkey (Aydın and Gencür 2014; Ateşoğlu and Türker 2013; Yağmur and Doğan 2017) in particular.

\subsection{Global economic risks and tourism}

The 2019 GRR (World Economic Forum 2019) contains nine major global economic risks. They include: asset bubbles in a major economy; deflation in a major economy; failure of a major financial mechanism or institution; failure/shortfall of critical infrastructure; fiscal crises in key economies; high structural unemployment or underemployment; illicit trade; severe energy price shock; and unmanageable inflation. While these risks have different implications for different economic sectors, tourism is uniquely affected by them. Asset bubbles impact tourism through financial crises, inflation, labor shortages and pollution (Zheng et al. 2010; Fortanier and van Wijk 2010; Güneralp and Seto 2008; Sheng 2011; Cai et al. 2006; Khan et al. 1990; Sheng and Tsui 2009; Smeral 2006). Prolonged near-zero inflation or deflation in a major tourist economy or region can disincentivize investment in tourism. Research shows that financial crises such as the 2008-2009 global financial crisis caused a significant downturn in tourist arrivals in a number of countries in Asia as well as in Australia (Prideaux 2010; Prideaux and Witt 2007). Failure of aging and insecure energy, transportation and communications infrastructure can have major short and long-term impacts on tourism. Excessive debt burdens in a key tourism economy endangers tourism sector (Wilde and Warren 2008; Ritchie et al. 2010). High structural unemployment significantly lowers tourism participation and expenditure by households (Alegre et al. 2013). Tourism sector is also exposed to illicit trade risks in forms of illicit financial flows, tax evasion, human trafficking, organized crime, etc. Organized crimes can deter tourists because security is an important concern for tourists (World Tourism Organization 1997; Van Dijk 2007). Moreover, research shows that countries with less corruption have a better developmental sustainability, which is the building block of sustainable tourism (Mekinc et al. 2013). Economic crises reduce the performance of tourist destinations (Perles-Ribes et al. 2016). National and international financial and economic crises since 2007 have severely affected global tourism. According to the World Tourism Organization (2011) international tourist arrivals decreased by $4 \%$ in 2009 due to financial crises. Because tourism is very energy intensive and therefore vulnerable and sensitive to energy price shocks. Energy price shocks impact demand for goods and services including tourism services (Becken 2011). While, the impacts and the risk mitigation and adaptation strategies vary, ability of tourism sector to adapt to these shocks are very essential for sustainable tourism. Finally, unmanageable high inflation rates play a major role in loosing competitive advantage in tourism as they did for New Zealand, Italy, Spain, Turkey, the United Kingdom, Hong Kong, and China (Dwyer et al. 2002). Although tourism companies have some control over pricing, they have little control over the inflation rates (Dwyer et al. 2002). Most recently, Turkish lira experienced 35\% devaluation (caused mainly by the US governments' new tariffs and sanction) and with high inflation and interest rates, tourism sector has been impacted (Kamin 2018; Kutukız 2005).

\subsection{Global environmental risks and tourism}

GRR (World Economic Forum 2019) considers five major global environmental risks including: extreme weather events; failure of climate-change mitigation and adaptation; major biodiversity loss and ecosystem collapse; major natural disasters; and man-made 
environmental damage and disasters. Extreme weather events such as floods, storms, extreme heat and cold waves have devastating impacts on tourism industry (Windle and Rolfe 2013). They can reduce tourists' interests in such destinations because tourists are generally sensitive to climate and weather and temperature have been very strong determinants of tourism demand (Bigano et al. 2005). Climate change is a major challenge for the tourism and has been affecting it and expected to have even more profound implications for tourism in the coming years (Scott et al. 2012; Tuna and Özyurt 2017). These impacts are realized in many forms including consumer destination choices, the spatial patterns of tourism demand, and the sustainability and competitiveness of destinations. Therefore, failure of climate-change mitigation and adaptation mechanisms and measures pose an important risk to tourism industry (Scott et al. 2016).

While unplanned tourism contributes to loss of biodiversity, ecotourism is an important and growing section of tourism that is highly dependent on biodiversity and ecosystem services. Major biodiversity loss and ecosystem collapse (terrestrial or marine) is a significant risk for this type of tourism. For example, studies show that damage to coral reefs have had irreversible implications for eco-tourism (Simpson 2003). Tursab and Tuader (2017) reported loss of flora and fauna as the result of unplanned tourism development in Muğla, Turkey. Major local and global extinctions of plant and animal species are projected which would impact eco-tourism (Simpson 2003). Therefore, reducing this risk very much depends on protection of biodiversity.

Catastrophic natural disasters events such as earthquake, tsunami, volcanic eruption, wildfire, geomagnetic storm are regularly impacting tourism sector (Ritchie et al. 2010). They damage tourism related infrastructure and facilities such as hotels, and resources such as tourist attraction sites, and deteriorate tourism destinations (Park and Reisinger 2010). Tourism demands for disaster impacted areas usually decreases after major disasters (Sharpley 2005). Examples of recent large disasters that impacted tourism industry are: the 2004 Asian Tsunami; the 2010 Eyjafjallajökull volcanic eruption in Iceland; the 2011 Great East Japan earthquakes and tsunami, 2011 flooding in Thailand, the 2010-2012 Christchurch, New Zealand, earthquakes, and the 2013 Southern Alberta flood in Canada (Rittichainuwat 2006; Scott et al. 2012). Significant number of the 2004 Indian Ocean Tsunami victims were tourists and people working for tourism industry (Thitthongkam and Walsh 2011). This event impacted the number of international tourists coming to the impacted countries such as Indonesia and Thailand for some years (Thitthongkam and Walsh 2011). Only in Phuket, Thailand, the number of international tourists decreased by $67.2 \%$ during the first half of 2005 (Kuo et al. 2008).

Being prone to several natural hazards such as flooding, earthquakes, and drought, natural disasters can affect tourism industry in Turkey. Major tourist destinations in Turkey are subject to high levels of seismic hazards and risks. A major earthquake can impact tourists, tourist infrastructure and facilities as well as cultural heritages that are among the driving forces of tourism development and growth in Turkey (Çetinsöz and Ege 2012; Ural 2015). For example, Eryigv et al. (2010) found that the 1999 Marmara (Izmit) earthquake had significant negative effects on tourism flow in Turkey.

Similarly, man-made environmental damage and disasters such as oil spills, radioactive contamination, etc. can heavily impact tourism sector. Large Oil spills such as the Deepwater Horizon oil spill in the Guelf of Mexico in 2010 pollute coastal zones and reduce their attractiveness to tourists. Travel to radioactive contaminated areas are diminished. Air pollution is a major environmental risk in big cities such as Istanbul (Tursab and Tuader 2017) which has great impact on tourists specially seniors that are more vulnerable to pollution risks. 


\subsection{Global geopolitical risks and tourism}

Failure of national governance, failure of regional or global governance, large-scale terrorist attacks, state collapse, and weapons of mass destruction are the five key geopolitical risks reported in the GRR (World Economic Forum 2019). Failure of national governance that reveals itself in form of failure of rule of law, corruption, political deadlock and instability have impacted tourism industry around the globe primely through the shift in travel demand and destinations (Abbasian 2018). For example, Saha and Yap (2015) evaluated the effects of political instability on tourism development in UNESCO-listed heritage destinations. They concluded that a one-unit increase in political instability decreases tourist arrivals and tourism revenue between 24 and 36\%. Corruption is considered as an impediment to tourism development and efficiency (Saha and Yap 2015; Ghialy and Shrabani 2013). Uncorrupt governments promote tourism through rules and regulations that enhance security and stability and try to create legal frameworks for protection of tourists and tourism industry (Williams 2004). Political corruption is fatal and is the source of huge risks for tourism industry (Saha and Yap 2015). Government corruption can also lead to public unrest and outcry that can affect tourism by creating safety concerns. Other forms of corruptions such as monopolies supported by corrupt politicians can limit the entry of small-businesses into the market (Torres 2003).

Failure of regional or global governance that represents itself in form of inability of regional or global institutions to resolve issues of economic, geopolitical, or environmental importance is another global risk that has huge implications for tourism. Recent examples include the UK exit from the European Union (Brexit) and the US government's withdrawal from international agreements and submits such as the Kyoto Protocol and the nuclear deal with Iran called the Joint Comprehensive Plan of Action (JCPOA). Existing international multilateral frameworks (i.e. United Nations) and agreements are important for the collective global security and can be expanded to include emerging global risks. Tourism is highly sensitive to the global security environment. Many of the existing regional and global institutions have an important tourism component which enhance the security and promote cooperation in tourism sector among the member states. In fact formation of regional collaboration in tourism is very much directed and driven by the regional and global institutions. Creation of some of the international arrangement such as the ASEAN Tourism Agreement have been partially driven by incidents such as the 9/11 and the 2002 Bali bombing incidents (Wong et al. 2011). Any action that weaken the international security arrangements can impact tourism and tourism investment immediately. Tourists behaviour and their choice of destinations, are extremely sensitive to their perceptions of risk and risk management systems (e.g., Richter and Waugh 1986; Gartner and Shen 1992; Hall and O'Sullivan 1996; Hall and Oehlers 2000).

Interstate conflicts not only reduce tourism activities in the conflict regions, but also damage tourism infrastructure and cultural heritages, and discourage investors interest in tourism investment. Many cultural properties, that are the key for tourism, have been attacked and damaged during the interstate and civil conflicts, by governments, rebels or rioters around the world (Brosché et al. 2017). "Terrorism is an enigmatic and compelling phenomenon, and its relationship with tourism is complex and multifaceted" (Baker 2014; 58). The impacts of terrorist attacks on tourism have been extensively studied in recent years (Abadie and Gardeazabal; 2003; Blomberg et al. 2004; Abadie 
and Gardeazabal 2008; Araz-Takay et al. 2009; Nitsch and Schumacher 2004; Eckstein and Tsiddon 2004). The impacts of large scale terrorist incidents may expand for many years as the impacted regions go through several complicated phases of response and recovery (Fletcher and Morakabati 2008). The impacts of the September 11, 2001 terrorist attacks on tourism still continues today (Fuchs et al. 2013). Although tourists' reactions and rationalizations of different terrorist attacks are not the same and magnitude of the impacts can vary from case to case, they are certainly of great concern for tourists and tourism companies. When the perceived risk of terrorism increases in one region or country, international tourists and investors choose to spend their vacation and money in safer regions or sectors (Fletcher and Morakabati 2008; Yaya 2009). Terrorism not only impacts tourism in the country of the incidents, but also it will have spillover effects in the whole region. For example, Bassil (2014) reported significant spill over impacts of terrorism between Turkey and the neighboring countries. The terrorism impacts are much more for countries that rely heavily on tourism and tourism has a high share in their GDPs. Repeated terrorist attacks have had significant direct and indirect impacts on tourism in Turkey (Yaya 2009; Onur 2018; TUROFED 2017; COMMEC 2017). Evidences from Turkey show that terrorist attacks were responsible for six million foreign tourists reduction in Turkey between 2000 and 2009 (Yaya 2009). Number of European tourists in Turkey decreased by $30 \%$ as the results of terrorist attacks targeting tourist infrastructure, facilities, and attractions. These attacks created an image of insecurity, which caused a significant decline in the number of international arrivals in Turkey (Aras 2017).

State collapse or crisis in form of civil conflict, military coup, failed states and so on are another global risk that is very important for tourism at national, regional and global levels. Studies show that political instability has severe consequences for tourism industry in the affected countries (Teye and Leclerc 1998). For example, a mix of political turmoil, military coup d'états, and the crisis of the Thai state during 2007-2009 heavily impacted Thai tourism industry. These events deterred international investors and tourists and made people involved in the Thai tourism industry very much uncomfortable (Cohen and Neal 2010). The 2008 events were very disruptive and caused a significant drop in tourist arrivals $(380,00)$ and tourism income $(5.0 \%)$ (Thitthongkam and Walsh 2011). Similar situation existed in the case of Lebanon, Colombia, and Sri Lanka for many years. Internal conflicts have resulted in lower revenues from tourism (Pradhan; 2001).

Weapons of mass destruction is the last risk under this category. It refers to the "deployment of nuclear, chemical, biological, and radiological technologies and materials, creating international crises and potential for significant destruction" (World Economic Forum 2019; 97). Lessons learned from the previous uses of such weapons including those used by the USA in Japan during the World War II and industrial accidents involving nuclear materials or release of highly toxic chemicals clearly show that these agents can destroy tourism for a very long period (Becker 2001).

Tourism in Turkey has been experiencing and impacted by a long list of geopolitical events and risks in recent years including the Syrian civil war since 2011, interstate conflicts in its border such as the conflict between the Russia and Ukraine and the Europe, failed coup attempt in 2016 and other international political changes (COMMEC 2017; Tuna and Özyurt 2017). 


\subsection{Global societal risks and tourism}

Failure of urban planning, food crises, large-scale involuntary migration, profound social instability, rapid and massive spread of infectious diseases, and water crises are the six main risks identified as societal global risks by the GRR (World Economic Forum 2019). Failure of urban planning that is revealed in form of poorly planned cities, urban sprawl and associated infrastructure that create social, environmental and health challenges is a key global risk with very specific implications for tourism. Urban planning and tourism development go hand in hand (Shoval 2018; Clavé 2019). Urban planning deficiencies can lead to the creation of urban agglomerations that are neither attractive to residents nor to tourists. These forms of planning create cities with no identity, connectivity, walkability, safety, security, and livability. Urban planning deficiencies such as absence of efficient urban transportation, heavy traffic and pollution, and lack of enough open and green spaces are threatening the sustainable and balanced growth of tourism (Tursab and Tuader 2017). On the other hand, tourism development without considering the local needs, cultures, and aspirations adds to the complexities. Despite the role that tourism plays in the local and national economies, residents protest unplanned tourism development are increasing (Khamdevi and Bott 2018). To address these issues and associated risks, urban tourism must be interconnected with urban planning, management and governance (Clavé 2019). Unplanned urbanization and urban planning issues have been cited as one of the problems facing Turkish tourism industry (Tursab and Tuader 2017).

Food crises is another global risk that can affect tourism and the problem in part is because tourism can contribute to food crises in the host communities by increasing demand for food, adding extra pressures on the environment, and turning agricultural land and resources to tourism activities. These pressures are already mounting in small island tourism countries in the Caribbean (Timms and Conway 2012) and dry countries in the Middle East and the Persian Guelf (Pirani and Arafat 2015).

Profound social instability in form of street riots, prolonged demonstrations, social unrest are examples of situations when social instability is also a global risk with major impacts on tourism. Social instability undermines tourism growth (Strange and Kempa 2003; Naudé and Saayman 2005; Weaver 2012; Fourie and Santana-Gallego 2013). Infectious diseases and global pandemics have been the great killers of human race on the planet and they are still posing major threat to the world as evidenced by the 2003 Severe Acute Respiratory Syndrome (SARS) pandemic, the 2009 Avian Influenza, and the 2014-2015 Ebola outbreak in Africa. International tourism, while it is a contributing factor in the transmission of diseases, it is also the prime victim of them. For example, presence of HIV/AIDS reduced the Thai's tourism industry's competitiveness (Thitthongkam and Walsh 2011). Such crises can have long lasting impacts by damaging the reputation and image of tourism industry. SARS had a profound negative impact on the global tourism, but generated the most negative impacts on tourism in countries with suspected cases in South-East Asian countries such as Thailand, Hong Kong, and China as well as Canada where travel advisories and restrictions were issued by the World Health Organization (Pine and McKercher 2004; Kuo et al. 2008; Thitthongkam and Walsh 2011). During the SARS crisis approximately 3 million people lost their jobs in the tourism industry in China, Hong Kong, Vietnam and Singapore (Huo and Miller 2007). According to Kuo et al. (2008) impacts of the Avian Flu and subsequent pandemic influenza on tourism was much higher than the SARS (Kuo et al. 2009). Turkey 
was among the countries that were severely infected by the avian flu outbreaks between 2003 and 2007 (Kuo et al. 2009). While there are references to the global epidemics such as Avian Flue in official reports in Turkey (TUROFED 2017; COMMEC 2018), this risk has not been subject to significant attention.

Large scale involuntary migration is another global risk in this category. Conflicts, climate change, and wars are creating waves of involuntary migration around the world. Global forced displacement will have short and long term economic, social, and political impacts and consequences for the host countries (Tumen 2016), particularly small communities that do not have the required capacity to absorb the incoming and additional population. Turkey received an estimated number of four million Syrian refugees during the past few years (Onur 2018). This flow of forced migration has had some impacts on tourism in the host cities. For example, it has been reported that tourism has died out in the city of Hatay after the Syrian refugee crisis began (ORSAM 2015). Also, considering that a large portion of the refugees are settled in large cities like Istanbul, this increases the pressure on the housing market and can indirectly impact tourism sector through possible increase in the accommodation costs.

Finally, like the food crises, water crises are also classified as global risk with huge implications for tourism. Even though, tourism generates a small fraction of the global water demand (less than 1\%) (Gössling et al. 2012), tourism is very much dependent on water, and water shortages in the host countries and regions create human health issues that can adversely impact tourism as well as residents. Water intensive and luxury tourism development can intensify this crisis and risk (Tekken and Kropp 2015). Without proper management of water resources, this risk will increase, particularly because of the climate change and changes in the global precipitation patterns (Cole 2014).

\subsection{Global technological risks and tourism}

Tourism like other industries is linked with technology Adverse consequences of technological advances, breakdown of critical information infrastructure and networks (Critical information infrastructure breakdown), large-scale cyber-attacks, and massive incident of data fraud/theft are listed as major global technological risks in the GRR (World Economic Forum 2019). Technological advances such as artificial intelligence, geo-engineering and synthetic biology have potential adverse intended or unintended consequences that can cause human, environmental, and economic damages. Tourism sector is not be immune from these impacts. Tourists and tourism industry are increasingly becoming dependent on the information technology and significant amount of tourism transactions are handled through the global information infrastructure and networks. Tourism is an information intensive industry and information technology in form of e-tourism has revolutionized tourism industry (Magobe et al. 2015) and "re-engineered the entire process of developing, managing and marketing tourism products and destinations" (Buhalis and O'Connor 2005, 207). E-tourism has expanded the market reach and improved the efficiency tourism industry (Magobe et al. 2015). Wide-scale breakdown and disruption of information infrastructure and networks have occurred in recent years due to natural and technological and human made hazards (Ding et al. 2015). Such disruptions can have severe consequences for tourists and tourism related businesses.

Large-scale cyber-attacks can also hinder tourism. Tourism industry has become increasingly reliant on the cyberspace that is increasingly subject to significant potential threats and vulnerabilities (Olding and Turner 2007). Like many other markets, in today 
tourism market is managed primarily in the cyberspace where stakeholders meet and transact. Large scale cyber-attacks on tourism related infrastructure such as financial, power and transportation networks pose a significant risk to tourism industry. Transportation networks have been targeted and attacked, to affect tourism (van Niekerk 2018). Protecting the cyberspace against cyber threats and risks has been and will continue to be a major challenge for the tourism industry (Olding and Turner 2007; Magliulo 2016).

With massive production and distribution of data on the cyberspace, data fraud and theft in form of wrongful exploitation of private or official data has grown up to an unprecedented scale (World Economic Forum 2019). While much of the data theft is for fraud and financial gains, the stolen data can also be used for malicious activities and attacks on touristic sites and events. Data fraud and theft are another e-tourism service supply chain risk that need to be mitigated or averted (Qin and Zhang 2013). Data theft and fraud in e-tourism is one of the areas that require immediate actions from both the governments and stakeholders in the tourism sector (Magobe et al. 2015).

\section{Methodology and data}

The methodology and data obtaining methods are given in Sects. 3.1 and 3.2, respectively.

\subsection{Risk analysis and assessment methodology}

This study is a risk analysis and assessment effort. Risk analysis can be performed using quantitative or qualitative approaches or a combination of both. The quantitative risk analysis is an objective analysis of risks based on the observed and calculated probability (or frequency) and magnitude of losses (or impact) of risk events. As such, it is a data intensive, complex, and time-consuming method and is used and preferred when enough data exist, and other methods are not sufficient. On the other hand qualitative risk analysis is based on the perceived (or subjective) values of likelihood and consequences of risk events, often provided by subject matter experts, practitioners, or decision makers. In this type of risk assessment, qualitative scales such as very unlikely to very likely (for likelihood), and minimal to catastrophic (for impact) are used. The qualitative risk analysis is widely used in practice, especially when conducting a quantitative assessment is not feasible because of data limitation and budget and time constraints (Modarres 2006). A mixed method is also possible in which some values are collected through objective calculations and some other through expert opinion. While data for quantitative assessment can be collected through existing records, laboratory experiments, modelling and simulations, data for qualitative risk assessment are collected through interviews, surveys, and focus groups.

In this study a qualitative risk analysis is applied for three main reasons. First, because the goal of the study is to apply the GRR method at national and industry specific contexts. Since the GRR uses a qualitative risk assessment method, this study also applies the same method. Second, conducting a quantitative risk assessment for the 30 listed risks in the GRR is a very time and data intensive task that is beyond the scope of this study. Third, in some cases, including this study, perceived risks provide valuable information for planning and policy makings.

In a multi risk assessment study such as this study, risks of different hazards are compared for risk evaluation and management purposes. Risk matrix is frequently used to display and rank the outcomes of the risk analysis. To create the risk matrix, likelihood 
values (or probabilities) and impacts (or consequences) are plotted in a two-dimensional space. Risk matrix provides some basis for risk treatments and management. Usually risks with higher likelihood and impact are considered as those that need to be mitigated or transferred to third parties through insurance. Risks that are higher in either likelihood or impact are those that need to be constantly monitored and or reduced. Risks that are in the lower part of the risk matrix can be classified as those that can be accepted. Risk matrices are being used in many levels and contexts such as local, regional, and national disaster risk analysis, enterprise and business risk analysis, terrorism risk analysis, infrastructure projects risk analysis, climate change risk management, etc. and their use is also recommended in some of the existing risk management standards (Cox 2008). Despite its wide use, risk matrix has been criticized by researchers and practitioners for its theoretical issues and its inability to embed risk preferences in the matrix (Cox 2008; Ni et al. 2010; Bao et al. 2017).

\subsection{Data}

To assess and analyze the risks based on the global risk report, a questionnaire was designed including 18 questions. In the first 10 sets of questions respondents were asked to provide their opinion about the likelihood and impacts of the global risks from their country and industry (tourism) perspectives. More specifically, participants were asked to assess (1) the likelihood of the risk occurring within the next 10 years, and (2) its negative impact for tourism in Turkey over the same timeframe. The likelihood of risks was measured using a five-scale ranging from "very unlikely" to "very likely" and coded from 1 to 5 during the analysis ( $1=$ very unlikely, $5=$ very Likely). In the second set of questions, respondents were asked to identify potential consequences of the global risks for Turkey. The choices were: "minimal", "minor", "moderate", "severe", and "catastrophic". Similarly, the risk impacts were coded from 1 to 5 for the analysis $(1=$ minimal and $5=$ catastrophic $)$. Some additional questions about the respondents' role and responsibility in the organization, number of people employed in the business, type of activity (hotel, tour operations, etc.), percent of international tourists among their customers, and the countries of origins of the international tourists were also asked.

Questionnaire was developed using Google Form which allows for easy, free, and flexible creation and distribution of questionnaires. Questionnaire was first piloted in a small sample of respondents. Respondents were recruited through the Anatolian Ankara Tourism Administrators Association (ATID). ATID has about 200 members that includes hotels, tour operators and some touristic restaurants. After several attempts 30 respondents completed the questionnaires survey. Although 30 is a high response rate for this type of survey (\%15), this sample may not be representative for the whole country and as such is a limitation of this study. This study can be expanded to include other industry associations and stakeholders. Majority of the respondents (21) are were from Ankara and the rest are from other places such as Istanbul, Kayseri, and Antalya. Majority of the respondents are from Hotel business (22) and the rest are tour operators or tourist experts and academics doing research in tourism. Hotels and tour operators provide services to both domestic and international tourists. International tourists come from various countries including Iran, Korea, Kyrgyzstan, Iraq, Syria, Azerbaijan, Russia, USA, Japan, Germany, India, Pakistan, Macedonia, Georgia, Spain, China, and Indonesia. Most of the respondents work as operation manager, general manager, tour leaders, chief operation officer, sale manager, executive 
manager, etc. Data was collected during March and April 2019. Researchers followed the Ankara Yeldirim Bayezit University's ethic protocols.

\section{Findings}

In this section the main findings of the study are presented. Section 4.1 provides the frequency tables related to the perceived likelihoods and impacts of different risks in each of the five global risk categories. Section 4.2 presents and interprets the risk matrix.

\subsection{Perceived likelihood and impacts}

Global Risk categories are examined and results are shown one by one in figures. Figure 1 shows the likelihood and impact frequencies of the economic risks as perceived by the respondents. Significant differences exist in both perceived likelihood and impact values between different global economic risks. Severe energy shock, unmanaged inflation, high structural unemployment, illicit trade, and asset bubbles are risks with the highest overall likelihoods (very likely and likely). Most of the respondents believed that catastrophic and severe impacts are expected as the results of unmanaged inflation, severe energy shocks, and fiscal issues in key economies.

Figure 2 presents the perceived likelihoods and impacts for global environmental risks. While majority of the respondents consider the likelihood of these risks to be somewhat likely, man-made environmental damage and disasters, and major natural disasters have higher overall sum of likely and very likely responses. Extreme weather events do not seem to be perceived as likely or very likely among the respondents. Most of the respondents perceive the impacts of man-made environmental and natural disasters to be catastrophic or severe.

Figure 3 shows the perceived likelihoods and impacts of the geopolitical risks. Except for the state collapse crisis, majority of the respondents believed that the likelihood of these global risks is somewhat likely. However, combining the very likely and likely responses, it appears that large scale terrorist attacks, interstate conflicts, and failure of national governance are of great concern from the likelihood point of view. Interestingly, majority of the respondents consider the impacts of geopolitical risks to be severe and combined with catastrophic almost all these risks are perceived to have severe and catastrophic impacts for tourism.

Figure 4 shows the perceived likelihood and impact frequencies among the 30 respondents for societal risks. Clear majority of the respondents perceived the likelihood of most of the societal risks to be either likely or very likely within the next 10 years, particularly, profound social instability, water and food prices as well as large scale involuntary migration and failure of urban planning. Only the rapid and massive spread of infectious diseases seem to have lower likelihood. Again, majority of the respondents consider the impacts of these risks to be severe.

Finally, Fig. 5 presents the perceived likelihoods and impacts of global technological risks. Except for the massive incident of dada fraud/theft, majority of the respondents perceive the likelihoods of these risks to be likely within the next 10 years. However, a good portion of the respondents consider the likelihood of these risks to be either somewhat likely or unlikely as well. This is particularly true for the breakdown of critical information infrastructure and networks. Almost similar patterns can be observed 
A

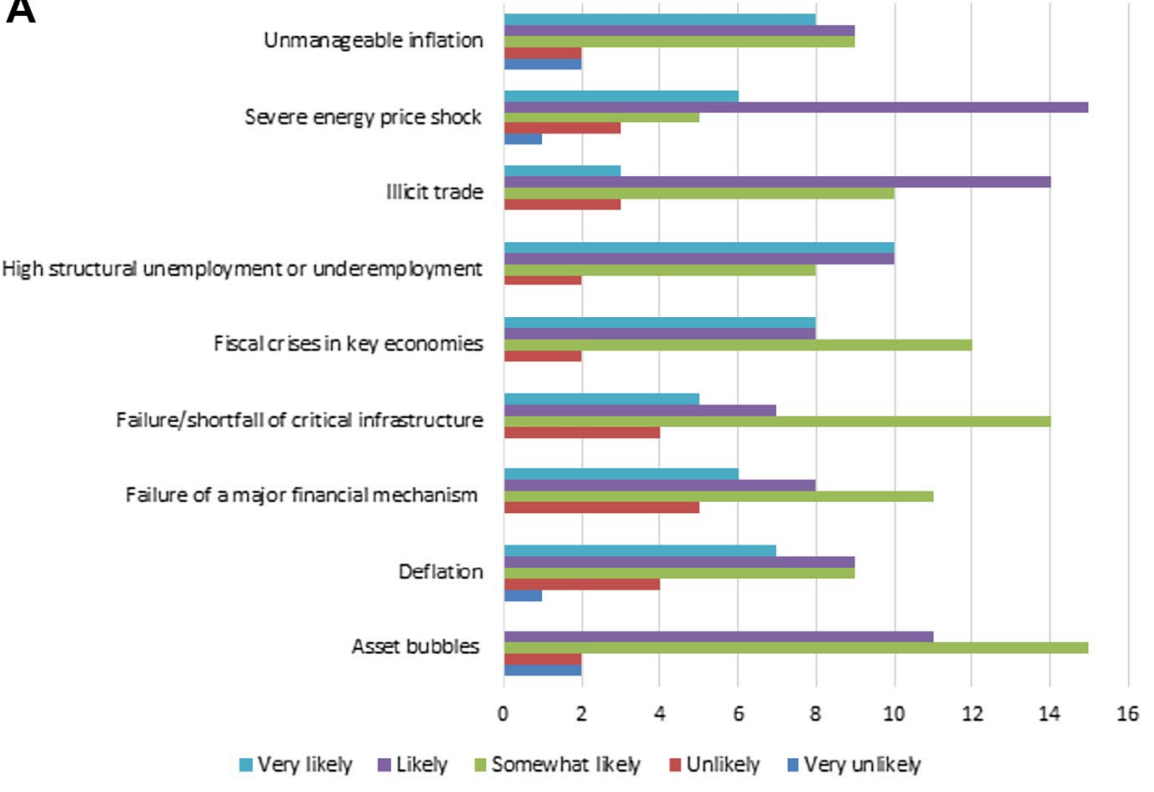

B

Unmanageable inflation

Severe energy price shock

Illicit trade

High structural unemployment or underemp loyment

Fiscal crises in key economies

Failure/shortfall of critical infrastructure

Failure of a major financial mechanism

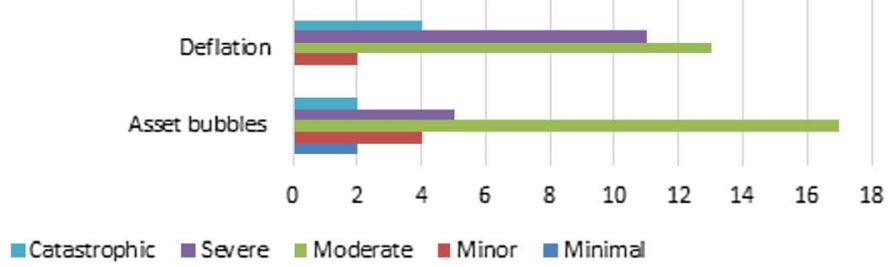

Fig. 1 a Perceived likelihood of global economic risks, $\mathbf{b}$ perceived impact of global economic risks 


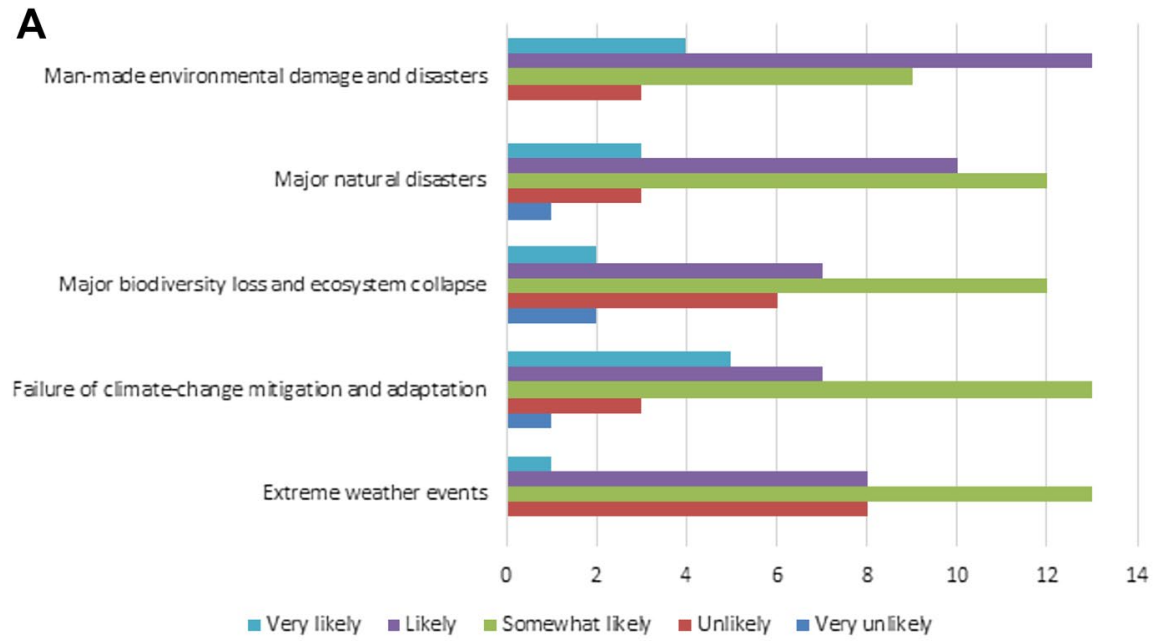

B

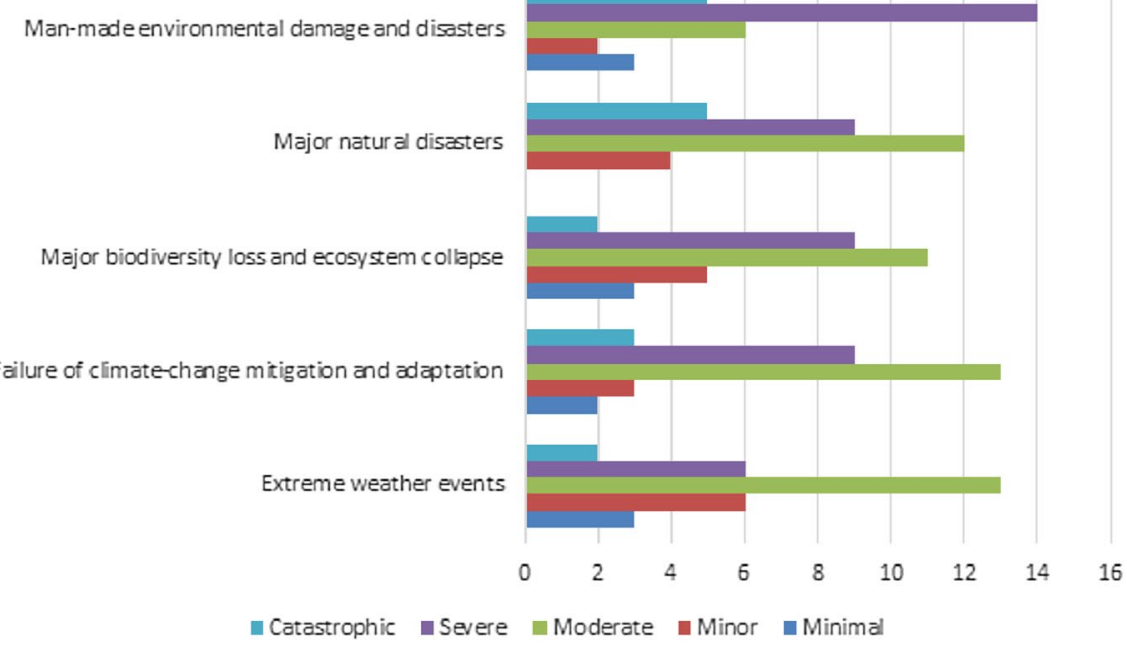

Fig. 2 a Perceived likelihood of global environmental risks, b perceived impact of global environmental risks

for the perceived impacts of the global technological risks. However, it seems that more respondents believed that the impacts of the global technological risks are minor or minimal compared to other types of risks.

In second part of this section top five global risks are ranked and given in Table 1.

Table 1 shows the top five global risks in terms of the likelihoods and impacts. Accordingly three economic risks are among the top 5 in terms of likelihood followed by two geopolitical risks. Also, three geopolitical risks and two economic risks are among the top 5 in terms of the impact. 
A

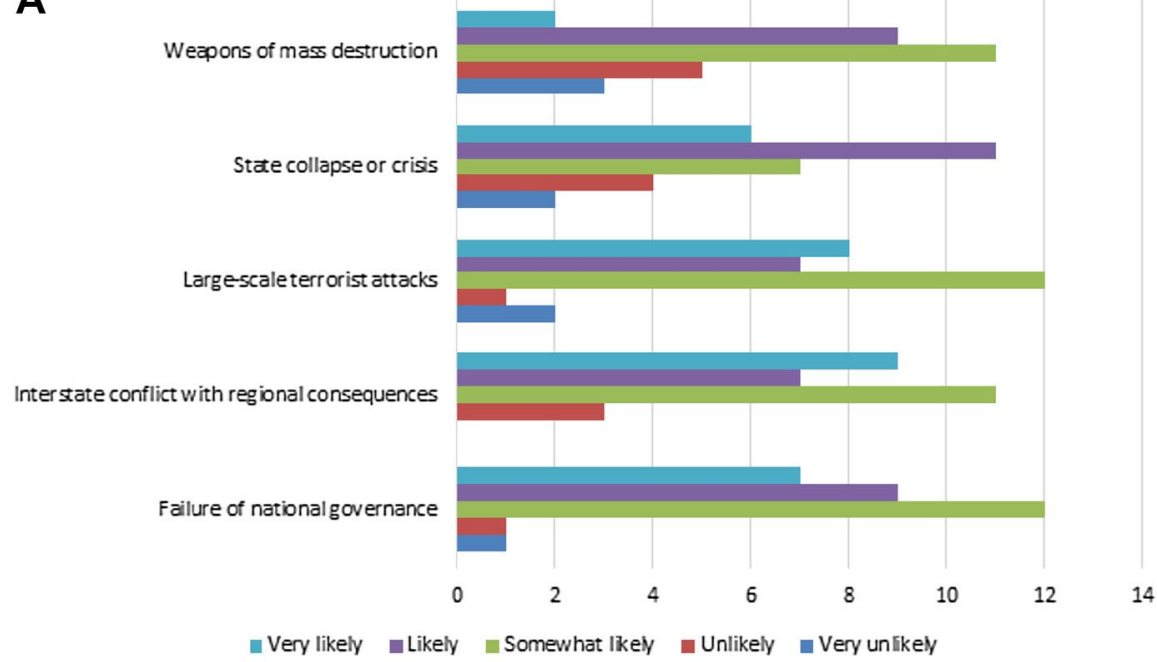

B

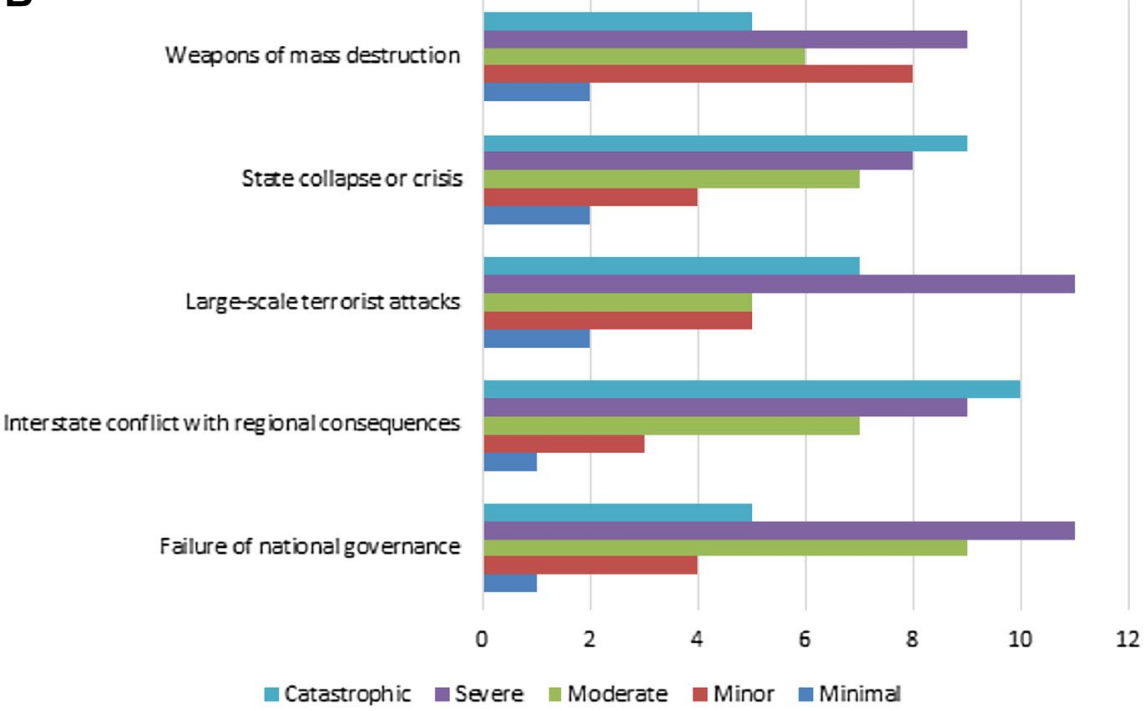

Fig. 3 a Perceived likelihood of global geopolitical risks, $\mathbf{b}$ perceived impact of global geopolitical risks

\subsection{Risk matrix}

Using the qualitative risk analysis methodology and perceived likelihoods and impacts, a risk matrix (plot) has been created. Table 2 shows the calculated mean values for the likelihoods and the impacts of all 30 global risks. The last column shows the assessed risk values that are calculated by multiplying the mean likelihoods by the mean impacts. 
A

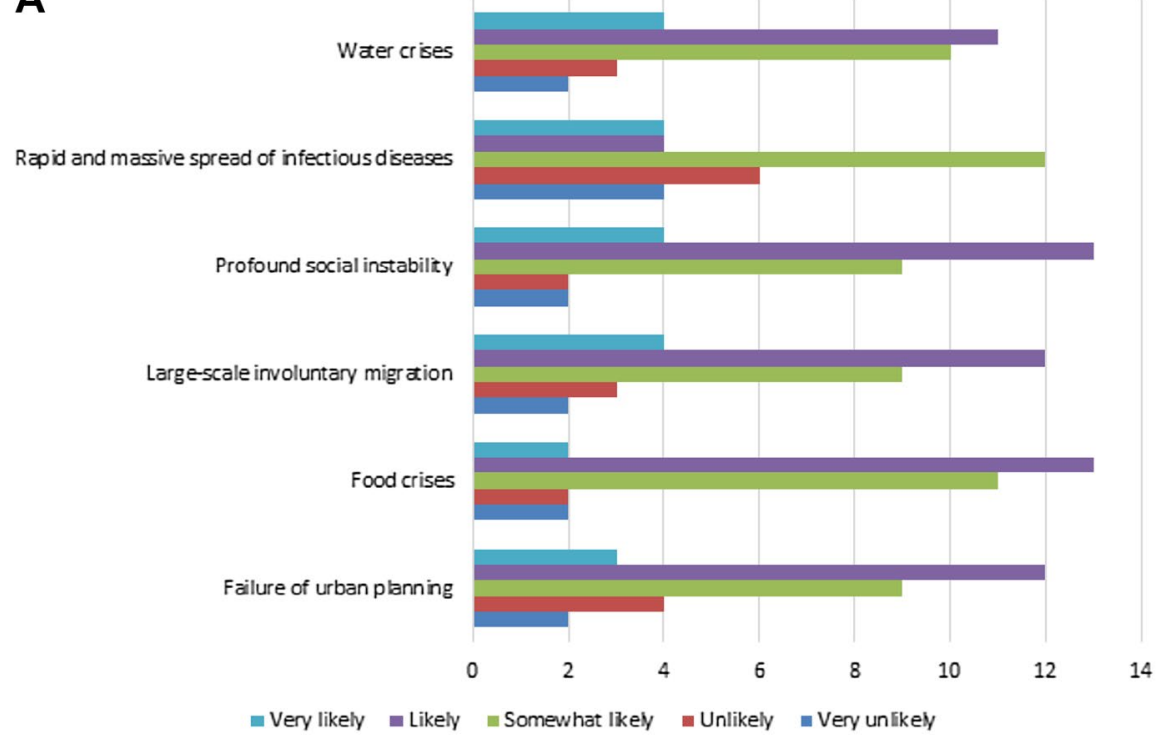

B

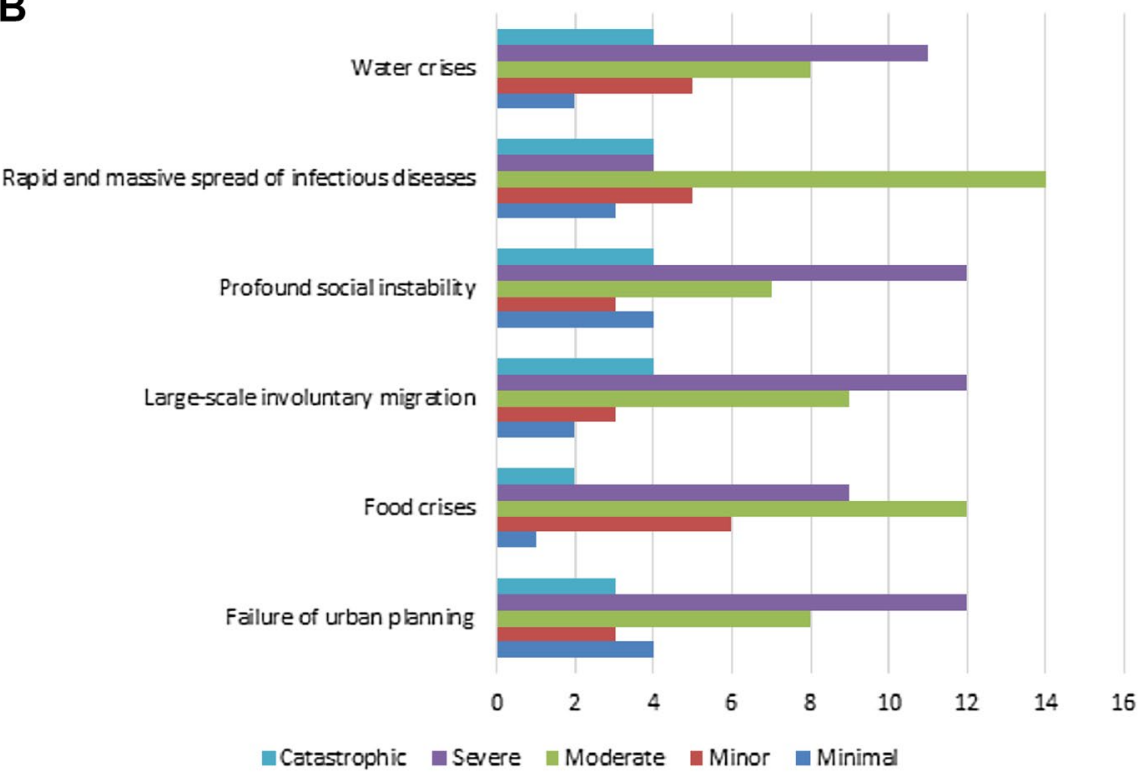

Fig. 4 a Perceived likelihood of global societal risks, b perceived impact of global societal risks

Figure 6 shows the calculated perceived risks sorted from high to low. Among the top 5 risks three are economic risks (High unemployment and underemplotment, fiscal crisis in key econimies and unmanageble inflation) and the other two are geopolitical risks (Failure of regional or global governance and Interstate conflicts). Two technological and two environmental risks are among the five lowest risks. 
A

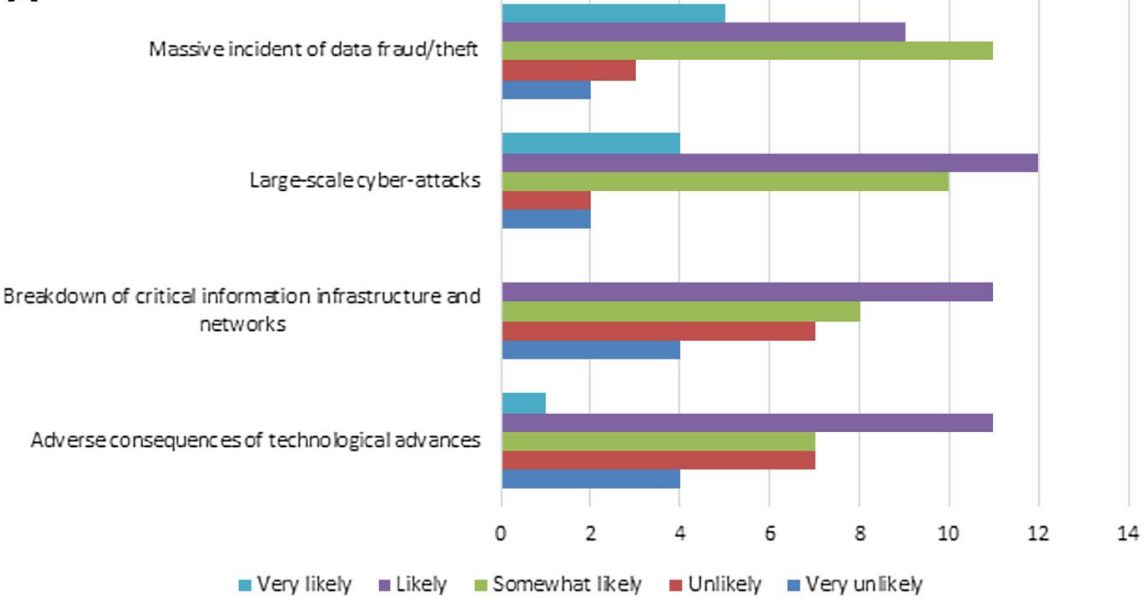

B

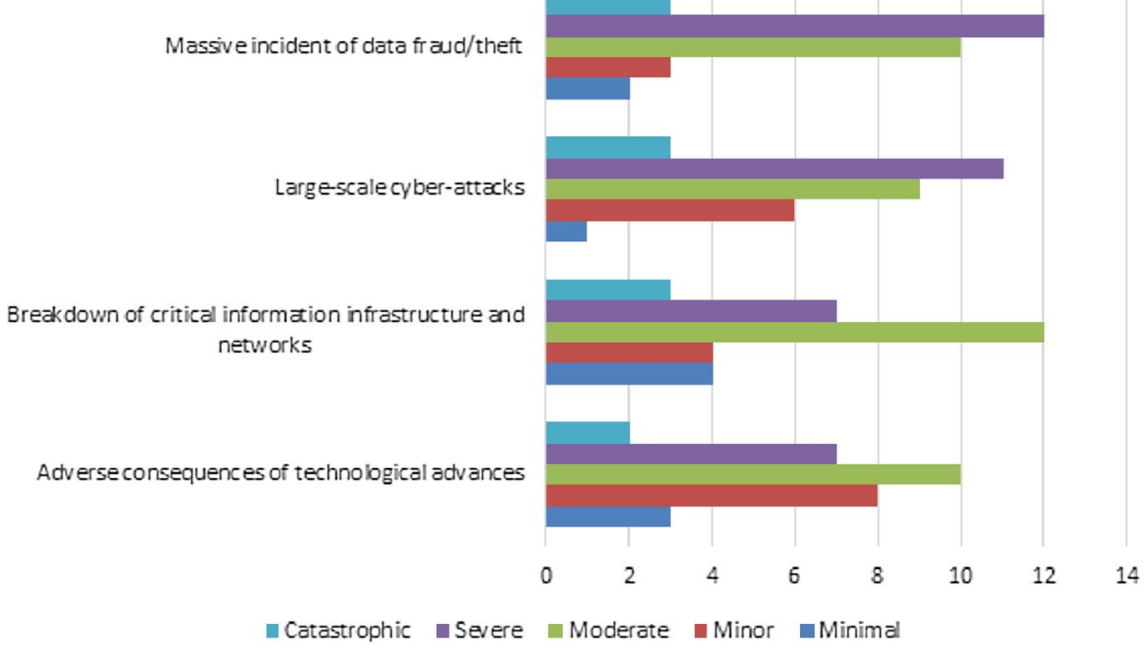

Fig. 5 a Perceived likelihood of global technological risks, $\mathbf{b}$ perceived impact of global technological risks

Table 1 Top five global risks in terms of likelihoods and impacts

Top five global risks in terms of likelihood for Truism Industry in Turkey (this study)

High structural unemployment or underemployment

Severe energy price shock

Fiscal crises in key economies

Failure of regional or global governance

Interstate conflict with regional consequences
Top five global risks in terms of impact for Truism Industry in Turkey (this study)

Failure of regional or global governance

State collapse or crisis

Unmanageable inflation

Deflation

Interstate conflict with regional consequences 
Table 2 Mean likelihood and impact of risks

\begin{tabular}{|c|c|c|c|c|}
\hline Risk category & Risk & $\begin{array}{l}\text { Mean Likeli- } \\
\text { hoods }\end{array}$ & $\begin{array}{l}\text { Mean } \\
\text { Impacts }\end{array}$ & $\begin{array}{l}\text { Risk }=\text { Likeli- } \\
\text { hood } \times \text { Impact }\end{array}$ \\
\hline \multirow[t]{9}{*}{ Economic } & Asset bubbles in a major economy & 3.17 & 3.03 & 9.61 \\
\hline & Deflation in a major economy & 3.57 & 3.57 & 12.74 \\
\hline & Failure of a major financial mechanism & 3.50 & 3.20 & 11.20 \\
\hline & $\begin{array}{l}\text { Failure/shortfall of critical infrastruc- } \\
\text { ture }\end{array}$ & 3.43 & 3.33 & 11.42 \\
\hline & Fiscal crises in key economies & 3.73 & 3.57 & 13.32 \\
\hline & $\begin{array}{l}\text { High structural unemployment or } \\
\text { underemployment }\end{array}$ & 3.93 & 3.47 & 13.64 \\
\hline & Illicit trade & 3.57 & 3.17 & 11.32 \\
\hline & Severe energy price shock & 3.73 & 3.33 & 12.42 \\
\hline & Unmanageable inflation & 3.63 & 3.60 & 13.07 \\
\hline \multirow[t]{5}{*}{ Environmental } & Extreme weather events & 3.07 & 2.93 & 9.00 \\
\hline & $\begin{array}{l}\text { Failure of climate-change mitigation } \\
\text { and adaptation }\end{array}$ & 3.41 & 3.27 & 11.15 \\
\hline & $\begin{array}{l}\text { Major biodiversity loss and ecosystem } \\
\text { collapse }\end{array}$ & 3.03 & 3.07 & 9.30 \\
\hline & Major natural disasters & 3.38 & 3.50 & 11.83 \\
\hline & $\begin{array}{l}\text { Man-made environmental damage and } \\
\text { disasters }\end{array}$ & 3.62 & 3.53 & 12.78 \\
\hline \multirow[t]{6}{*}{ Geopolitical } & Failure of national governance & 3.47 & 3.50 & 12.15 \\
\hline & $\begin{array}{l}\text { Interstate conflict with regional con- } \\
\text { sequences }\end{array}$ & 3.67 & 3.57 & 13.10 \\
\hline & $\begin{array}{l}\text { Failure of regional or global govern- } \\
\text { ance }\end{array}$ & 3.73 & 3.80 & 14.17 \\
\hline & Large-scale terrorist attacks & 3.60 & 3.53 & 12.71 \\
\hline & State collapse or crisis & 3.50 & 3.60 & 12.60 \\
\hline & Weapons of mass destruction & 3.07 & 3.23 & 9.92 \\
\hline \multirow[t]{6}{*}{ Societal } & Failure of urban planning & 3.33 & 3.40 & 11.32 \\
\hline & Food crises & 3.37 & 3.23 & 10.89 \\
\hline & Large-scale involuntary migration & 3.43 & 3.17 & 10.87 \\
\hline & Profound social instability & 3.50 & 3.43 & 12.01 \\
\hline & $\begin{array}{l}\text { Rapid and massive spread of infectious } \\
\text { diseases }\end{array}$ & 2.93 & 3.30 & 9.67 \\
\hline & Water crises & 3.40 & 3.33 & 11.32 \\
\hline \multirow[t]{4}{*}{ Technological } & $\begin{array}{l}\text { Adverse consequences of technologi- } \\
\text { cal advances }\end{array}$ & 3.03 & 3.40 & 10.30 \\
\hline & $\begin{array}{l}\text { Breakdown of critical information } \\
\text { infrastructure and networks }\end{array}$ & 3.33 & 2.90 & 9.66 \\
\hline & Large-scale cyber-attacks & 2.93 & 3.03 & 8.88 \\
\hline & Massive incident of data fraud/theft & 2.87 & 3.30 & 9.47 \\
\hline
\end{tabular}

Figure 7 presents the risks matrix for the 30 risks. This matrix plots the means of perceived impacts and likelihoods for each risk. Risks located in the darker red zone are those that have higher than average values of either impact or likelihood or both. As such risks located on the top right corner of the matrix are the highest risks and those in the lower left corner of the matrix are low risk. Interestingly most economic risks except the asset 


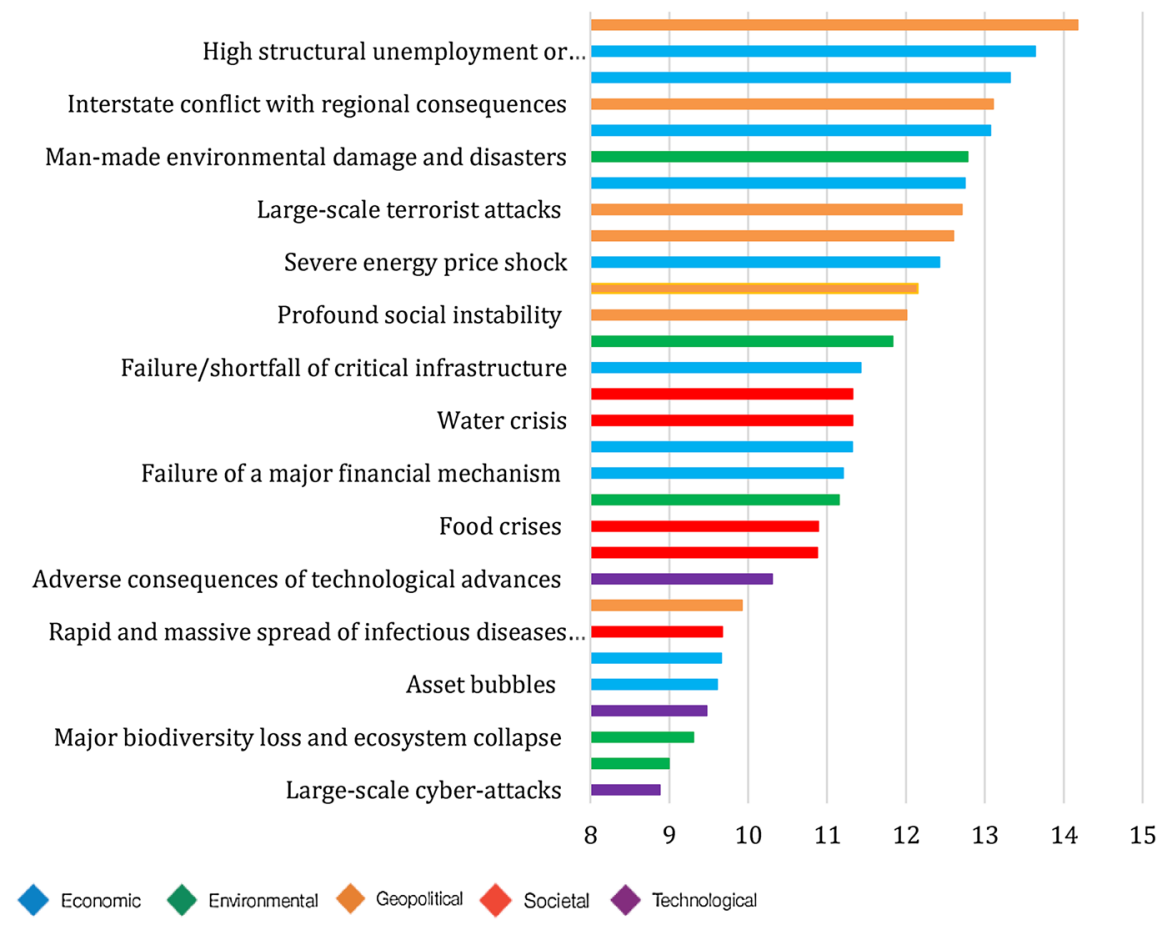

Fig. 6 Risks values sorted from the highest to the lowest

bubbles are in the red zone and many of them in the dark red zone. Similarly, all geopolitical risks except the weapon of mass destruction are at the red zone. All environmental risks except the major natural disaster risks are in the green or low risk zone. Technological risks are plotted either in the lower part of the red zone or the green area. Societal risks are mainly scattered in the middle part of the risk matrix.

\section{Discussion}

As expected the results of this study are different from the global risk report results despite using the same methodology. Some of the differences are discussed here.

1. Significant differences are observed between the top 5 risks in the Global Risk Report (World Economic Forum 2019, p. 8) and the findings of this study (Table 1). The 2019 GRR lists extreme weather events, failure of climate change mitigation and adaptation measures, natural disasters, data fraud and theft, and cyber attacks as the top five risks. Considering the current world economic conditions in general and Turkey's economy, these differences are not surprising. Moreover, Turkey and its tourist sector are being impacted by the failure of regional and global governance and interstate conflicts in the region. These are naturally of concern for tourism industry for the next 10 years.

2. Similarly, noticeable differences exist between the top five risks in terms of impacts between this study (Table 1) and the GRR. In the 2019 GRR weapons of mass destruc- 


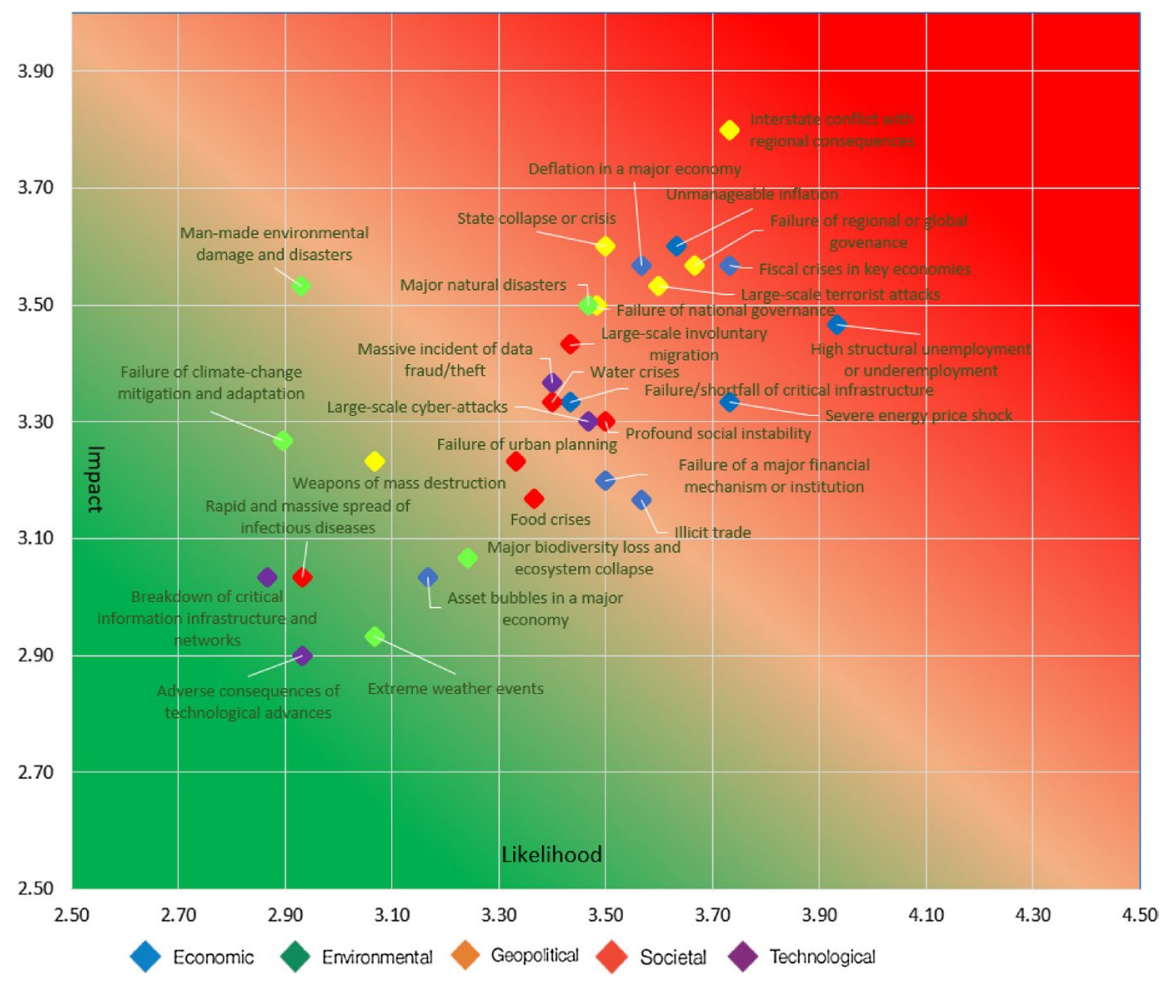

Fig. 7 Risk matrix

tion, failure of climate-change mitigation and adaptation, extreme weather events, water crises, and natural disasters are among the top five global risks (World Economic Forum 2019: 8). While most of the environmental risks are among the top 5 risks in terms of the impacts in the GRR, in this study three geopolitical risks and two economic risks are among the top 5 risks. These findings may suggest that country and industry views of the global risks may be different depending on the contexts in which the respondents operate in.

3. The differences are also reflected in the risk matrixes. For example, while many economic risks in the global risk report matrix are in the lowest quarter of the plot (World Economic Forum 2019, p. 5), in this study majority of the economic risks are ranked high and located in the upper quarter of the risk matrix. Similarly, most of the environmental risks are in the upper quarter of the risk matrix for the global risk report, but in this study most of them fall in the lower quarter. This seems to suggest that tourism industry in Turkey perceive the global economic and geopolitical risks to be more important than technological or environmental risks. In part this may reflect the fact that economic risks and geopolitical risks are fresh in respondents' memory as Turkey is currently dealing with the economic and political issues related to the global economic and geopolitical risks.

4. Societal risks also show different patterns between the two studies. In the GRR (World Economic Forum 2019, p. 5), societal risks are scattered in different parts of the matrix with water crisis and large-scale involuntary migration to be above the average and in 
the high-risk areas, societal risks are concentrated in the middle part of the risk matrix in this study with infectious disease to be in the low risk zone of the matrix. This is interesting because, despite the ongoing refugee crisis generated by the Syrian crisis, the Turkish tourism industry does not perceive it as to be as high.

5. These differences can also be explained by the fact that some global risks in some parts of the world may be opportunities for some industries in other parts of the world. For example, while inflation in a major economy or terrorist attacks in a major tourist region of the world can be considered as global risks from a general perspective, they might be opportunities for tourism sector in another part of the world since tourists shift their destination to low cost, safer, or healthier destinations.

\section{Conclusions}

This study applied the global risk report methodology at a country and industry specific level to understand how national and industry contexts and conditions affect assessment of the global risks. Using the case of tourism industry in Turkey, findings showed that significant variances exist in the perceived likelihoods and impacts of risks and their ranks between the global and the country/industry levels. These findings demonstrate that for national actors at specific industries like tourism global risks can be perceived, assessed and evaluated differently. However, more studies of this nature are needed for other sectors and/or other countries with a more representative samples to make further conclusions about the nature of these differences.

Considering the importance of tourism for the global and national economies, it is important that global risks are analyzed and monitored at national and regional levels. This will provide policy and decision makers with the needed information to manage the risks and develop their tourism industry based on the implications of the global risks. Moreover, this will help tourism industry to become part of the solution in reducing some of these risks through its ability to reduce the conflicts, increase employment and income opportunities and by educating tourists to be mindful of the global environmental risks that will impact tourism opportunities for the current and future generations.

Acknowledgement This research has been supported by TUBITAK through the 2221-Fellowship Program for Visiting Scientists and Scientists on Sabbatical Leave.

\section{References}

Abadie, A., Gardeazabal, J.: The economic costs of conflict: a case study of the Basque country. Am. Econ. Rev. 93(1), 113-132 (2003)

Abadie, A., Gardeazabal, J.: Terrorism and the world economy. Eur. Econ. Rev. 52(1), 1-27 (2008)

Abbasian, S.: Political crises and destination choice: an exploratory study of Swedish-Iranian second-home buyers. Tour. Cult. Commun. 18(3), 205-218 (2018)

Alegre, J., Mateo, S., Pou, L.: Tourism participation and expenditure by Spanish households: the effects of the economic crisis and unemployment. Tour. Manag. 39, 37-49 (2013)

Aras, H.: The problem of tourism security in Turkey. Hitit Univ. J. Soc. Sci. Inst. 10(1), 585-610 (2017)

Araz-Takay, B., Arin, K.P., Omay, T.: The endogenous and non-linear relationship between terrorism and economic performance: Turkish evidence. Def. Peace Econ. 20(1), 1-10 (2009)

Ateşoğlu, I., Türker, A.: Types of risks perceived in choosing tourist holiday destinations: a case study of Turkey. J. Travel Hosp. Manag. 10(3), 24-44 (2013) 
Aydın, A., Gencür, A.S.: Türkiye'nin Turizm Arzı, Piyasa Yapısı ve Global Riskler: Keşifsel Bir Yaklaşım. Optim. J. Econ. Manag. Sci. 2(2), 43-64 (2014)

Baker, D.M.A.: The effects of terrorism on the travel and tourism industry. Int. J. Relig. Tour. Pilgr. 2(1), 9 (2014)

Bao, C., Wu, D., Wan, J., Li, J., Chen, J.: Comparison of different methods to design risk matrices from the perspective of applicability. Procedia Comput. Sci. 122, 455-462 (2017)

Bassil, C.: The effect of terrorism on tourism demand in the middle east. Peace Econ. Peace Sci. Public Policy 20(4), 669-684 (2014)

Becken, S.: Review article: a critical review of tourism and oil. Ann. Tour. Res. 38(2), 359-379 (2011)

Becker, S.M.: Are psychosocial aspects of WMD incidents addressed in the federal response plan: summary of an expert panel. Mil. Med. 166, 66-68 (2001)

Bigano, A., Goria, A., Hamilton, J.M., Richard S., Tol, J.: The effect of climate change and extreme weather events on tourism, FEEM Working Paper No. 30.05 CMCC Research Paper No. 01 (2005)

Blomberg, S., Hess, G., Orphanides, A.: The macroeconomic consequences of terrorism. J. Monet. Econ. 51, 1007-1032 (2004)

Brosché, J., Legnér, M., Kreutz, J., Ijla, A.: Heritage under attack: motives for targeting cultural property during armed conflict. Int. J. Herit. Stud. 23(3), 248-260 (2017)

Buhalis, D., O’Connor, P.: Information communication technology revolutionizing tourism. Tour. Recreat. Res. 30(3), 7-16 (2005)

Cai, J., Leung, P., Mak, J.: Tourism's forward and backward linkages. J. Travel Res. 45(1), 36-52 (2006)

Çetinsöz, B.C., Ege, Z.: Risk reduction strategies according to demographic features of tourists: the case of Alanya. Anatolia: Turizm Araştırmaları Dergisi, Cilt 23, Sayı 2, Güz: 159-172 (2012). http:// dergipark.gov.tr/download/article-file/154435 Accessed 29 Mar 2019

Clavé, A.S.: Urban tourism and walkability. In: Fayos-Solà, E., Cooper, C. (eds.) The Future of Tourism. Springer, Cham (2019)

Cohen, E., Neal, M.: Coinciding crises and tourism in contemporary Thailand. Curr. Issues Tour. 13(5), 455-475 (2010)

Cole, S.: Tourism and water: from stakeholders to rights holders, and what tourism businesses need to do. J. Sustain. Tour. 22(1), 89-106 (2014)

COMMEC: Risk and crisis management in tourism sector: recovery from crisis in the OIC Member Countries (2017). http://www.sbb.gov.tr/wp-content/uploads/2018/11/Ris_and_Crisis_Manag ement_in_Tourism_Sector-.pdf. Accessed 29 Mar 2019

Cox, L.: What's wrong with risk matrices? Risk Anal. 28(2), 497-512 (2008)

Culture \& Tourism Ministry: Tourism Statistics: General Assessment 2018 (2018). http://yigm.kultu rturizm.gov.tr/Eklenti/62462,2018turizmgenelistatistiklerpdf.pdf?0 Accessed 29 Mar 2019

Cutter, S.L., Ismail-Zadeh, A., Alcántara-Ayala, I., Altan, O., Baker, D.N., Briceño, S., Gupta, H., Holloway, A., Johnston, D., McBean, G.A., Ogawa, Y., Paton, D., Porio, E., Silbereisen, R.K., Takeuchi, K., Valsecchi, G.B., Vogel, C., Wu, G.: Pool knowledge to stem losses from disasters. Nature 522(7556), 277-279 (2015)

de Amorim, W.S., Valduga, I.B., Ribeiro, J.M.P., Williamson, V.G., Krauser, G.E., Magtoto, M.K., de Andrade, J.B.S.O., et al.: The nexus between water, energy, and food in the context of the global risks: an analysis of the interactions between food, water, and energy security. Environ. Impact Assess. Rev. 72, 1-11 (2018)

Ding, D., Conti, M., Figueiredo, R.: Wide-scale internet disconnection: impact and recovery on socialbased P2P overlays. J. Latex Class Files 14(8), 1-14 (2015)

Dwyer, L., Forsyth, P., Rao, P.: Destination price competitiveness: exchange rate changes versus domestic inflation. J. Travel Res. 40(3), 328-336 (2002)

Eckstein, Z., Tsiddon, D.: Macroeconomic consequences of terror: theory and the case of Israel. J. Monet. Econ. 51(5), 971-1002 (2004)

Engel, U., Strasser, H.: Global risks and social inequality: critical remarks on the risk-society hypothesis. Can. J. Sociol. 23(1), 91-103 (1998)

Eryigv, M., Kotil, E.A., Eryigv, R.: Factors affecting international tourism flows to Turkey: a gravity model approach. Tour. Econ. 16(3), 585-595 (2010)

Fletcher, J., Morakabati, Y.: Tourism activity, terrorism and political instability within the commonwealth: the cases of Fiji and Kenya. Int. J. Tour. Res. 10, 537-556 (2008)

Fortanier, F., van Wijk, J.: Sustainable tourism industry development in sub-Saharan Africa: consequences of foreign hotels for local employment. Int. Bus. Rev. 19(2), 191-205 (2010)

Fourie, J., Santana-Gallego, M.: Ethnic reunion and cultural affinity. Tour. Manag. 36, 411-420 (2013)

Fuchs, M., Abadzhiev, A., Svensson, B., Höpken, W., Lexhagen, M.: A knowledge destination framework for tourism sustainability: a business intelligence application from Sweden. Tourism 61(2), 121-148 (2013) 
Gartner, W.C., Shen, J.: The impact of Tiananmen square on China's tourism image. J. Travel Res. 30(4), 47-52 (1992)

Ghialy, Y., Shrabani, S.: Do political instability, terrorism, and corruption have deterring effects on tourism development even in the presence of unesco heritage? A cross-country panel estimate. Tour. Anal. 18(5), 587-599 (2013)

Gössling, S., Scott, D., Michael Hall, C., Ceron, J., Dubois, G.: Consumer behaviour and demand response of tourists to climate change. Ann. Tour. Res. 39(1), 36-58 (2012)

Güneralp, B., Seto, K.C.: Environmental impacts of urban growth from an integrated dynamic perspective: a case study of Shenzhen. South China Global Environ. Change 18(4), 720-735 (2008)

Hall, C.M., O’Sullivan, V.: Tourism, political stability and violence. In: Pizam A, Mansfeld Y (eds.) Tourism, Crime and International Security Issues, pp. 105-121. Wiley, New York (1996)

Hall, C.M., Oehlers, A.L.: Tourism and politics in South and Southeast Asia: political instability and policy. In: Hall, C.M., Page, S.J. (eds.) Tourism in South and Southeast Asia: Critical Perspectives, pp. 77-94. Butterworth-Heinemann, Oxford (2000)

Huo, Y., Miller, D.: Satisfaction measurement of small tourism sector (Museum): Samoa. Asia Pac. J. Tour. Res. 12(2), 103-117 (2007)

Kamin, D.: Another hit for Turkish Tourism (2018). https://www.nytimes.com/2018/08/15/travel/turke y-tourism-economic-crisis.html. Accessed 28 Mar 2019

Kaufman, G.G., Kenneth, E.S.: What is systemic risk, and do bank regulators retard or contribute to it? Indep. Rev. 7(3), 371-391 (2003)

Khamdevi, M., Bott, H.: Rethinking tourism: Bali's failure. Friendly City 4 'From Research to Implementation for Better Sustainability'. IOP Publishing IOP Conference Series: Earth and Environmental Science 126, 1-10 (2018)

Khan, H., Seng, C.F., Cheong, W.K.: Tourism multiplier effects on Singapore. Ann. Tour. Res. 17(3), 408418 (1990)

Kuo, H.-I., Chen, C.-C., Tseng, W.-C., Ju, L.-F., Huang, B.-W.: Assessing impacts of SARS and avian flu on international tourism demand to Asia. Tour. Manag. 29(5), 917-928 (2008)

Kuo, H.I., Chang, C.L., Huang, B.W., Chen, C.C., McAleer, M.: Estimating the impact of avian flu on international tourism demand using panel data. Tour. Econ. 15, 501-511 (2009)

Kutukız, D.: Turizm Sektöründe Döviz Riski ve Korunma Yöntemleri. MUFAD J. 28, 198-207 (2005)

Magliulo, A.: Cyber security and tourism competitiveness. Eur. J. Tour. Hosp. Recreat. 7(2), 128-134 (2016)

Magobe, M.J., Kim, Y.B., Chang, B.Y.: E-commerce applications in the tourism industry: a Tanzania case study. S. Afr. J. Bus. Manag. 46(4), 53-64 (2015)

Mekinc, J., Kociper, T., Dobovsek, B.: The impact of corruption and organized crime on the development of sustainable tourism. J. Crim. Justice Secur. 15(2), 218-239 (2013)

Modarres, M.: Risk Analysis in Engineering Techniques, Tools, and Trends. Taylor \& Francis Group, New York (2006)

Naudé, W.A., Saayman, A.: Determinants of tourist arrivals in Africa: a panel data regression analysis. Tour. Econ. 11(3), 365-391 (2005)

Ni, H., Chen, A., Chen, N.: Some extensions on risk matrix approach. Saf. Sci. 48(10), 1269-1278 (2010)

Nitsch, V., Schumacher, D.: Terrorism and international trade: an empirical investigation. Eur. J. Polit. Econ. 20, 423-433 (2004)

Olding, A., Turner, P.: Cyber vulnerabilities and the tourism industry: developing a conceptual framework. In: ACIS 2007 Proceedings, 116 (2007)

Onur, B.F.: Turkey: a crossroads of risk and opportunities (2018). http://www.hurriyetdailynews.com/turke y-a-crossroads-of-risk-and-opportunities-136068. Accessed 08 Mar 2019

ORSAM: Effects of Syrian refugees on Turkey. ORSAM, Ankara, Report No. 195 (2015)

Park, K., Reisinger, Y.: Differences in the perceived influence of natural disasters and travel risk on international travel. Tour. Geogr. 12(1), 1-24 (2010)

Perles-Ribes, J.F., Ramón-Rodríguez, A.B., Sevilla-Jiménez, M., Moreno-Izquierdo, L.: Unemployment effects of economic crises on hotel and residential tourism destinations: the case of Spain. Tour. Manag. 54, 356-368 (2016)

Pine, R., McKercher, B.: The impact of SARS on Hong Kong's tourism industry. Int. J. Contemp. Hosp. Manag. 16(2), 139-143 (2004)

Pirani, S.I., Arafat, H.A.: Reduction of food waste generation in the hospitality industry. J. Clean. Prod. 132(20), 129-145 (2015)

Pradhan, G.: Economic cost of Sri Lanka's ethnic conflict. J. Contemp. Asia 31(3), 375-384 (2001)

Prideaux, B.: Tourism perspectives of the asian financial crisis: lessons for the future. Curr. Issues Tour. 2(4), 279-293 (2010) 
Prideaux, B., Witt, S.F.: The impact of the Asian financial crisis on Australian tourism. Asia Pac. J. Tour. Res. 5(1), 1-7 (2007)

Qin, J., Zhang, L.: Risk analysis of E-tourism service supply chain. In: 2013 Proceedings Annual Reliability and Maintainability Symposium (RAMS), Orlando, FL, pp. 1-5 (2013)

Richter, L.K., Waugh, W.L.: Terrorism and tourism as logical companions. Tour. Manag. 7(4), 230-238 (1986)

Ritchie, J.R.B., Amaya Molinar, C.M., Frechtling, D.C.: Impacts of the world recession and economic crisis on tourism: North America. J. Travel Res. 49(1), 5-15 (2010)

Rittichainuwat, B.N.: Tsunami recovery. A case study of Thailand's tourism. Cornell Hotel Restaur. Admin. Q. 47(4), 390-404 (2006)

Saha, S., Yap, G.: Corruption and tourism: an empirical investigation in a non-linear framework. Int. J. Tour. Res. 17(3), 272-281 (2015)

Scott, D.C., Hall, C.M., Gössling, S.: Tourism and Climate Change, Impacts, Adaptation and Mitigation, 1st edn. Routledge, London (2012)

Scott, D.C., Hall, C.M., Gössling, S.: A report on the Paris Climate Change Agreement and its implications for tourism: why we will always have Paris. J. Sustain. Tour. 24(9), 933-948 (2016)

Sharpley, R.: The tsunami and tourism: a comment. Curr. Issues Tour. 8(4), 344-349 (2005)

Sheng, L., Tsui, Y.: Casino boom and local politics: the city of Macao. Cities 26(2), 67-73 (2009)

Sheng, Li: Foreign investment and urban development: a perspective from tourist cities. Habitat Int. 35(1), 111-117 (2011)

Shoval, N.: Urban planning and tourism in European cities. Tour. Geogr. 20(3), 371-376 (2018)

Simpson, M.: Tourism, livelihoods, biodiversity, conservation and the climate change factor in Africa. NATO Advanced Research Workshop on 'Climate Change and Tourism: Assessment and Coping Strategies', Warsaw, Poland, 6-8 November (2003)

Smeral, E.: Tourism satellite accounts: a critical assessment. J. Travel Res. 45(1), 92-98 (2006)

Strange, C., Kempa, M.: Shades of dark tourism: Alcatraz and Robben Island. Ann. Tour. Res. 30(2), 386-405 (2003)

Tekken, V., Kropp, J.P.: Sustainable water management-perspectives for tourism development in northeastern Morocco. Tour. Manag. Perspect. 16, 325-334 (2015)

Teye, V.B., Leclerc, D.: Product and service delivery satisfaction among North American cruise passengers. Tour. Manag. 19(2), 153-160 (1998)

Thitthongkam T., Walsh J.: An analysis of factors influencing the competitiveness of the Thai Tourism Industry (2011). https://s3.amazonaws.com/academia.edu.documents/30876032/30-B1000 7.pdf?AWSAccessKeyId=AKIAI WOWYYGZ2Y53UL3A\&Expires $=1555375878 \&$ Signa ture $=3 \mathrm{HR} 4 \mathrm{Oz0PL} \% 2 \mathrm{BDpWmdv0mBiB} 9 \mathrm{j} 9 \mathrm{FaQ} \% 3 \mathrm{D} \&$ response-contentdisposition=inline $\% 3 \mathrm{~B} \% 20$ filename\%3DAn_Analysis_of_Factors_Influencing_the_C.pdf. Accessed 15 Apr 2019

Timms, B.F., Conway, D.: Slow tourism at the Caribbean's geographical margins. Tour. Geogr. 14(3), 396-418 (2012)

Torres, R.: Linkages between tourism and agriculture in Mexico. Ann. Tour. Res. 30(3), 546-566 (2003)

Tumen, S.: The economic impact of Syrian refugees on host countries: quasi-experimental evidence from Turkey. Am. Econ. Rev. 106(5), 456-460 (2016)

Tuna, M., Özyurt, B.: Türkiye Turizm Sektöründe Risk Yönetimi”, 3. Turizm Şurası Tebliğler Kitabı, 1-3 Kasim 2017, Ankara, pp. 164-173 (2017)

TUROFED: Tourism Report (2017). http://dosya.turizmguncel.com/2017_rapor.pdf. Accessed 09 Mar 2019

TÜRSAB \& TUADER: Turizm Sektör Raporu, 2017 Ocak-Haziran Dönemi (2017). https://www.tursa b.org.tr/tr/tursabdan-haberler/kurumsal-haberler/tursab-tuader-turizm-sektor-raporu-yayinlandi _16736.html

UN (United Nations): World Population Prospects: The 2015 Revision, Key Findings and Advance Tables. Department of Economic and Social Affairs, Population Division. Working Paper No. ESA/P/WP.241 (2015). http://esa.un.org/unpd/wpp/Publications/Files/Key_Findings_WPP_2015.pdf

Ural, M.: Importance of risk management for the sustainability of tourism. Balıkesir Univ. J. Soc. Sci. Inst. 18(33), 163-178 (2015)

Van Dijk, J.: Mafia markers: assessing organized crime and its impact upon societies. Trends Organ Crim. 10(39), 39-56 (2007)

van Niekerk, B.: Analysis of cyber-attacks against the transportation sector. In: Cyber Security and Threats: Concepts, Methodologies, Tools, and Applications. University of KwaZulu-Natal, South Africa (2018)

Weaver, B.: Organic, incremental and induced paths to sustainable mass tourism convergence. Tour. Manag. 33(5), 1030-1037 (2012) 
Wilde, W.D., Warren, M.J.: Visualisation of critical infrastructure failure. In: Proceedings of the 9th Australian Information Warfare and Security Conference, Edith Cowan University, Perth Western Australia, 1st December (2008)

Williams, A.M.: Toward a political economy of tourism. In: Lew, A.A., Hall, M.C., Williams, A.M. (eds.) A Companion to Tourism, pp. 61-73. Blackwell Publishing, Oxford (2004)

Windle, J., Rolfe, J.: The impacts of the 2011 extreme weather events on holiday choices of Brisbane residents. Australas. J. Environ. Manag. 20(4), 338-350 (2013)

Wong, E.P.Y., Mistilis, N., Dwyer, L.: A model of ASEAN collaboration in tourism. Ann. Tour. Res. 38(3), 882-899 (2011)

World Economic Forum: The Global Risks Report 2019. World Economic Forum, Geneva (2019)

World Tourism Organization: Annual Report (2011) http://cf.cdn.unwto.org/sites/all/files/pdf/annual_repor t_2011.pdf. Accessed 15 Apr 2019

World Tourism Organization: Report (1997). http://cf.cdn.unwto.org/sites/all/files/docpdf/472csa36dec.pdf. Accessed 15 Apr 2019

WTTC-World Travel\&Tourism Council: Travel \& Tourism Economic Impact 2019. https://www.wttc.org/ economic-impact/country-analysis/\#undefined. Accessed 15 Apr 2019

Yağmur, Y., Doğan, O.: Foreign tourists' risk perceptions about Turkey: an application in Antalya region. Turizam 21(2), 90-101 (2017)

Yaya, M.E.: Terrorism and tourism: the case of Turkey. Defence Peace Econ. 20(6), 477-497 (2009)

Zheng, S., Kahn, M.E., Liu, H.: Towards a system of open cities in China: home prices, FDI flows and air quality in 35 major cities. Reg. Sci. Urban Econ. 40(1), 1-10 (2010)

Publisher's Note Springer Nature remains neutral with regard to jurisdictional claims in published maps and institutional affiliations. 